\title{
O poder monárquico e a saúde do corpo feminino na Castela do século XIII
}

\author{
Monarchical power and the health of the female body in 13th century \\ Castile
}

\begin{abstract}
Cleiton de Oliveira Batista ${ }^{1}$
Marta de Carvalho Silveira ${ }^{2}$

${ }^{1}$ Graduado e Licenciado em História pela Universidade do Estado do Rio de Janeiro. Professor de história - Pré-Vestibular Social CEFET e professor de história do Instituto Educacional RFC Lago. E-mail: cleitonoliveira06@gmail.com.

2 Possui Graduação e Licenciatura em História pela Universidade Federal do Rio de Janeiro (1993), Mestrado em História Social pela Universidade Federal do Rio de Janeiro (1996) e Doutorado em História Antiga e Medieval pela Universidade Federal Fluminense (2012). Atualmente é Professora Adjunta da Universidade do Rio de Janeiro, onde atua na área de História Medieval. É professora também da Universidade Estácio de Sá, atuando na graduação presencial e na modalidade EAD no curso de licenciatura e bacharelado em História. E-mail: martadecarvalhosilveira@gmail.com.
\end{abstract}

Recebido em 29 de março de 2021; Aceito em 25 de junho de 2021.

DOI: $10.12957 /$ nearco.2021.58945

\section{Resumo}

A saúde do corpo feminino é um dos temas presente em algumas das obras produzidas na corte castelhana de Afonso X. Nosso objetivo é refletir sobre como e por que os cuidados em relação à saúde feminina foram considerados relevantes pelo monarca e pelo seu círculo intelectual a ponto de estarem presentes em obras tratadísticas como - Lapidário de Afonso $X$, que apresenta prescrições para o uso de pedras com fins profiláticos.

Palavras-chave: Relações de Poder; Discurso Médico; Discurso Jurídico.

\begin{abstract}
The health of the female body is one of the themes present in some of the works produced in the Castellan court of Afonso X. Our objective is to reflect on how and why the medical care in relation to female health was considered relevant by the monarch and his intellectual circle to the point of being present in treatises such as the Lapidary of Alfonso $X$, which presents prescriptions for the use of stones for prophylactic purposes.
\end{abstract}

Keywords: Power Relations; Medical Discourse; Legal Discourse. 


\section{Introdução}

Nesse trabalho pretendemos analisar como o conhecimento geológico e médico presente no Lapidário de Afonso $X^{88}$ (LAX) contribuiu para apresentar tratamentos e medidas preventivas em relação a dois elementos fundamentais para a saúde feminina: a menstruação e o aleitamento.

Nossa análise se circunscreve ao campo da história do conhecimento, em um intercâmbio com a história social das mulheres, na medida em que pretendemos mapear os conhecimentos médicos que foram veiculados pelo Lapidário para garantir a saúde das mulheres de forma a que elas estivessem saudáveis para cumprir a sua função social primordial: gerar e cuidar dos seus filhos.

Como método para o tratamento das fontes utilizamos a análise de discurso, nos moldes que propôs Orlandis (2012), ao buscar compreender a autoria, a mensagem e o receptor do discurso como elementos que, coordenados, garantem o sentido do que é dito e que se encontra imerso no conjunto simbólico próprio de um contexto, prestando-se, inclusive, ao reforço das categorias de poder. Como afirma Orlandis ${ }^{89}$ sobre a atenção que se deve ter ao lidar com o discurso: “[...] A entrada no simbólico é irremediável e permanente: estamos comprometidos com os sentidos e o político."

Nesse sentido, portanto, interessa-nos analisar as relações de poder que se estabelecem no campo discursivo entre a monarquia e o corpo social.

\section{O ordenamento do corpo social e a saúde feminina}

O século XIII, em Castela e no restante do Ocidente medieval, foi marcado por uma busca pela centralidade de poder por parte dos monarcas. Seguindo os passos de seu pai, Fernando III, que havia conseguido reunir as coroas castelhana e leonesa após anos de separação, Afonso X investiu não somente nas ações militares que lhe garantiu

\footnotetext{
88 Utilizaremos a abreviatura LAX para referir-nos ao Lapidário ao longo do texto.

89 ORLANDIS, E. P. Análise de discurso. Princípios e procedimentos. Campinas: Pontes, 2012. p. 9
} 
a ampliação do território real, mas também buscou ordenar e garantir a paz e o convívio harmônico entre as comunidades cristãs, muçulmanas e judaicas que espalhavam-se pelo reino, equilibrando-se para não chocar seus interesses centralizadores com os interesses políticos dos elementos nobiliárquicos. Para tanto, Afonso X empenhou-se em fazer da sua corte um espaço de produção de conhecimentos que se estendiam desde o campo do jurídico até o campo dos estudos sobre a natureza (física).

Cercado de sábios e de juristas das mais diversas origens, Afonso $\mathrm{X}$ financiou e estimulou a atividade das escolas de tradução, especialmente a de Toledo. No scriptorium afonsino textos oriundos da tradição filosófica clássica, como os escritos de Aristóteles, e do oriente chegavam à Castela intermediados, sobretudo, por sábios judeus e muçulmanos. A corte castelhana foi reconhecida como uma das mais culturalmente ativas do medievo, o que rendeu ao rei Afonso, a alcunha de O Sábio. Nicasio Salvador, ao referir-se à produção cultural existente na corte afonsina, salientou:

Copistas, traductores, ajuntadores, miniaturistas, músicos, muchos de cuyos hombres conocemos y de cuyas reuniones las pinturas de la Las Cantigas, y en grado inferior las de otros textos, conservan belos bocetos, se agrupan en los centros de trabajo de Toledo y Sevilla, sobre todo, pero también de Murcia y Burgos. ${ }^{90}$

O LAX é um tratado geológico e se remete à tradição de uma série de catálogos produzidos, no século VIII, a partir do Libro de las piedras, de Jabir bem Hayyan. Em sua tese, ao tratar da classificação dos seres no Lapidário de Afonso X (2008), Carlinda Mattos lembra que a origem dos lapidários remonta à Índia, à Pérsia e à Mesopotâmia e que se tornaram muito apreciados e difundidos no Ocidente a partir do período alexandrino, dando origem a diversas versões. Como afirma a historiadora:

Copiados e recopilados, esses tratados acrescentam, recombinam e enriquecem seu gênero, constituindo-se numa tradição viva, continuamente retomada ao longo do tempo, no Oriente e no Ocidente, tendo sido muito numerosos na Idade Média." ${ }^{91}$

\footnotetext{
${ }^{90}$ SALVADOR, Nicasio Miguel. El intelectual. In: VALDEÓN, J., SALVADOR, N, LÓPEZ ESTRADA, E. e MARÉN, M. La España de Alfonso X. Cuadernos Historia 16. v. 13, 1985, p. 13.

91 MATTOS, Carlinda Maria Fischer. A Classificação Dos Seres No Lapidário De Afonso X, o Sábio. Tese. Universidade Federal do Rio Grande do Sul. Porto Alegre. 298 p. 2008. p. 53. Disponível em https://lume.ufrgs.br/handle/10183/15896
} 
Escrito originalmente em árabe, a obra foi traduzida para o castelhano, na corte afonsina, entre os anos de 1243 e 1250, sob a coordenação de Yehuda ben Moses alCohen Mosca, médico judeu, conhecedor da astronomia. Essa obra é composta por quatro tratados onde são apresentadas as características físicas de cada uma das pedras, identificadas as suas potencialidades curativas e informadas as condições astronômicas/astrológicas em que as pedras devem ser manipuladas para aumentar o seu potencial curativo. O primeiro tratado presente no Lapidário é atribuído a Abolays e nele são apresentadas 360 pedras, embora somente 300 delas tenham chegado até nós. O segundo tratado, onde são descritas 36 pedras, e o terceiro tratado, que apresenta 63 pedras, são anônimos. Já o quarto tratado foi atribuído a Mohamat Abenquich e contém informações sobre 46 pedras.

Para esse artigo limitamos a nossa análise ao primeiro lapidário atribuído a Abolays. Nossa escolha se deu por três motivos. O primeiro motivo é que ele é o mais extenso e o mais completo, apesar da perda de informações sobre algumas pedras. 0 segundo motivo é que ele é um dos únicos lapidários que têm a sua autoria identificada e, em seu prólogo, descreve a trajetória do manuscrito desde a sua origem até a sua chegada à corte afonsina. Além disso, é o único dos lapidários que tem como principal foco os usos medicinais das pedras. Como a nossa análise buscou relacionar o conhecimento médico presente no tratado com as determinações legais afonsinas, especialmente no que tange à garantia de que as mulheres medievais cumprissem adequadamente o seu papel maternal, o lapidário de Abolays nos ofereceu elementos significativos para alcançar tal objetivo.

O discurso médico, geológico, astronômico/astrológico e mágico existente no LAX se remete ao sistema de pensamento analógico que concebia o homem medieval como um microcosmo reprodutor das características presentes no macrocosmo, onde a natureza e as suas diversas manifestações estavam localizadas. 
No que se refere ao conhecimento médico, o pensamento analógico se manifestou a partir do padrão da cura pelo semelhante e pelo contrário. ${ }^{92}$ É possível identificar esse padrão na descrição de duas das pedras presentes no LAX analisadas nesse trabalho: a Sedinech ${ }^{93}$, que é vermelha, e utilizada para impedir o sangramento feminino excessivo e a Zarocan ${ }^{94}$, branca, e com a virtude de estimular a produção do leite materno.

Os padrões naturais foram utilizados no tratamento medicinal a partir da semelhança ou contrariedade. Tal padrão pode ser percebido tanto nos seres animados, como os animais e plantas, quanto em seres inanimados, que não possuem alma. ${ }^{95}$ Nesse segundo grupo se encaixavam as pedras de um modo geral e "a eficácia que se Ihes atribuía ocorria por simpatia, ou seja, pela relação que existe entre sua forma, sua cor, seu sexo e a afecção que se pretendia curar." 96 Por isso, nos trechos apresentados anteriormente a pedra de cor vermelha foi atribuída às doenças relacionadas ao sangue e a branca ao aleitamento.

A concepção analógica medieval foi herdada das escolas filosóficas gregas pautadas na tradição aristotélica que consideravam o entendimento do mundo natural como primordial para a compreensão da realidade. No Prólogo do LAX identificamos a forte influência do pensamento aristotélico ao relacionar os elementos do macrocosmo e do microcosmo ao tratamento e a prevenção dos males do corpo.

Aristóteles, que fue más cumplido de los otros filósofos, y el que más naturalmente mostró todas las cosas por razón verdadera, y las hizo entender cumplidamente según son, dijo que todas las cosas que son sólo velos se mueven y se enderezan por el movimiento de los cuerpos celestiales, por la virtud que han de ellos, según lo ordenó Dios, que es la primera virtud y donde la han todas las outra. ${ }^{97}$

\footnotetext{
92 FRANCO Jr. Hilário. Similibus simile cognoscitur. O pensamento analógico medieval. Medievalista. Lisboa, v. 14, 2013. p. 8-14

${ }^{93}$ AFONSO X. Lapidário del Rey D. Alfonso X: Códice original. Madrid: Imprenta de La Iberia. 188, p. 43.

94 LAX, p. 15.

${ }^{95}$ Aqui se utiliza o conceito de seres animados e inanimados da teoria de Aristóteles.

96 FRANCO Jr. Hilário. op. cit., p. 15

97 LAX, p. 1.
} 
O entendimento de que os corpos celestes exerciam influência sobre os corpos humanos é a tônica central do LAX, que deveria ser consultado por aqueles que quisessem manipular pedras para fins medicinais. Por isso, no AXL foram indicados não somente os nomes das pedras, mas também as condições astrológicas sob as quais elas deveriam ser manipuladas para que se alcançasse a eficácia almejada.

Ao tratar da disposição do conhecimento médico no LAX, Dianina Rabelo considerou que:

A organização das pedras ao longo do tratado baseia-se na teoria ptolomaica, segundo a qual todos os corpos no mundo estão conectados e os mais altos (mais nobres) influenciam os baixos (mais vis). Assim, todos os seus tratados estão estruturados a partir da concepção astrológica segundo a qual as virtudes das pedras, sejam preventivas ou curativas, advém de astros e conjunções astrais em momentos propícios. Nessa perspectiva, as pedras encontram-se associadas aos elementos aos quais, por analogia, se conectam astrologicamente, recebendo suas virtudes. ${ }^{98}$

A relação existente entre o macrocosmo e o macrocosmo sustentou o pensamento analógico medieval e influenciou a forma como a saúde do corpo humano foi entendida na Idade Média.

A base do pensamento médico medieval foram as teorias de Hipócrates e de Galeno. Em linhas gerais, a teoria humoral definia os elementos da natureza como concebidos a partir de quatro elementos: terra, fogo, água e ar. Estes circulavam nos seres humanos através de quatro qualidades (calor, secura, frio e umidade) que se relacionavam aos quatro humores existentes: o sanguíneo (calorosos e amável), o fleumático (apático e lento), o bilioso ou colérico (agressivo e sisudo) e o melancólico (deprimido e triste). A identidade dos elementos constitutivos do universo (macrocosmo) fazia-se representar no corpo humano (microcosmo) e as doenças eram consideradas como resultantes do desequilíbrio dos humores. A função da física era, portanto, promover o reequilíbrio do corpo através da alimentação e da manipulação de vegetais e minerais na produção de unguentos e beberagens a serem administradas aos enfermos.

\footnotetext{
98 RABELO, D. R. S. Um olhar para o céu e para as pedras: conhecimento científico no Lapidario de Afonso X de Castela (século XIII). Tese defendida na UFG, 2019, p. 132.
} 
Seguindo uma tradição de conhecimento sobre a natureza que remonta à Antiguidade, o LAX, de acordo com o indicado em seu Prólogo, foi resultado de um amplo esforço intelectual dos diversos sábios envolvidos na sua redação para a compreensão da relação existente entre o mundo físico e os corpos humanos. Partindo da premissa aristotélica buscou-se identificar a constituição e o movimento dos astros, bem como as virtudes dos corpos celestes, a fim de explorar as suas potencialidades no tratamento dos males físicos.

A complexidade do conhecimento que envolvia as virtudes naturais das pedras e a sua manipulação nas condições astrológicas para potencialização dos seus efeitos curativos pressupõe que somente os homens sábios poderiam entender as informações contidas no LAX e manuseá-las adequadamente.

O cuidado com a saúde dos súditos fazia parte da esfera de interesse dos monarcas, como podemos perceber em uma das leis prevista na Quinta Partida ${ }^{99}$ onde determinava-se a punição pecuniária para aqueles que usassem de forma incorreta as pedras destinadas ao tratamento médico. A lei 10, presente no título 8, estabelecia que os físicos, os cirurgiões e os albeítares (veterinários) que recebessem dos seus pacientes pedras preciosas para o tratamento de um mal físico e, por não saber manuseá-las terminassem por quebrá-las, deveriam pagar “[...] la estimación de ella a bien vista de hombres buenos y conocedores de estas cosas." 100

O conhecimento médico proposto no LAX dialogava com uma concepção organicista de poder que situava o monarca na cabeça do corpo social, sendo o responsável por sua saúde e ordenamento, seguindo a tendência do raciocínio analógico.

\footnotetext{
${ }^{99}$ Uma das obras mais importantes do direito medieval, as Sete Partidas foram elaboradas a pedido do rei Afonso X ao seu corpo de juristas. Essa obra de caráter enciclopedístico é composta por sete livros, subdivididos em títulos e leis, e reúne elementos dos direitos romano, canônico e comum.

${ }^{100}$ ALFONSO X. Partida V, título VIII, lei 10. Las siete partidas de Don Alfonso X. Barcelona: Imprenta de Antonio Bergnes, 1843-1844.
} 
A concepção organicista que garante ao rei o poder ordenador do corpo social foi explicitada pelos juristas afonsinos no Prólogo do Fuero Real ${ }^{101}$, onde estabeleceu-se uma clara analogia entre a corte celeste e a corte terrestre. Entendia-se que a corte celeste foi ordenada por Cristo no céu, onde ele era a cabeça e o líder dos anjos e arcanjos, e a corte terrestre deveria seguir esse mesmo ordenamento ${ }^{102}$.

Como ordenador do corpo social, coube ao rei, através do aparato legal, regular as questões referentes também ao casamento dos seus súditos. Contudo, isso não significava a imposição, pelo rei, de uma normativa que se sobrepusesse àquela estabelecida pela Igreja que, a partir do IV Concílio de Latrão (1215), concebeu o casamento como um sacramento. Por isso, o Fuero Real determinava que o monarca e os seus súditos deveriam seguir as regras previstas pelas autoridades eclesiásticas ${ }^{103}$, mas caberia aos juristas afonsinos regular as questões práticas e patrimoniais decorrentes das relações matrimonias como a legitimidade da escolha dos cônjuges ${ }^{104}$, a determinação dos dotes e a regulação das heranças dos viúvos e dos filhos, como passaremos a observar agora.

O casamento era uma peça tão fundamental na consolidação da identidade social e jurídica feminina que para assegurar a todas as mulheres o direito de se casar, o FR determinava a idade limite de vinte e cinco anos para que as donzelas pudessem contrair matrimônio sem o consentimento da sua parentela. ${ }^{105}$ Nenhuma família poderia, então, manter uma mulher sob a sua custódia sem casá-la. As donzelas órfãs, por exemplo, poderiam se casar sem a autorização dos seus irmãos, contudo, se os pais estivessem vivos, seria deserdada se insistisse em se casar sem o seu consentimento ${ }^{106}$.

\footnotetext{
101 Uma das obras jurídicas produzidas na corte afonsina, o Fuero Real é um código de leis formado por quatro livros subdivididos em títulos e leis, esse conjunto normativo, assim como as Sete Partidas, reuniu elementos do direito canônico, do direito romano e do direito comum.

102 FR, Prólogo, 9

${ }^{103} \mathrm{FR}, \mathrm{III}, \mathrm{I}, 1$.

${ }^{104}$ Era estabelecida a penalização corporal para aqueles que se casassem com parceiros pertencentes a status socioeconômicos e religiosos diferenciados. Cf. FR, IV, XI, 1.

${ }^{105}$ Caso a donzela não fosse casada pelos seus parentes até os vinte e cinco anos, teria o direito de contrair as bodas sem nenhuma autorização parental. Cf. FR, III, I, 6.

106 FR, III, I, 5.
} 
Já as viúvas gozaram de uma autonomia legal mais ampla do que as das outras mulheres, pois detinham o direito de se casar sem nenhuma autorização parental ${ }^{107}$, mas deveriam esperar pelo menos um ano para voltar a contraírem novas bodas ${ }^{108}$.

Nota-se no projeto legal afonsino, portanto, o estímulo e à preservação do casamento, bem como a valorização da maternidade, que se expressa na proteção oferecida pela legislação às mulheres grávidas e aos seus filhos. Qualquer tipo de penalização corporal, mesmo após a instauração do processo, que envolvesse açoitamento ou a morte, era vedado às mulheres grávidas, que somente poderiam ser confinadas à prisão. ${ }^{109} \mathrm{O}$ direito da mulher grávida à herança também estava assegurado, bem como a seu filho ou filha, mesmo após a morte do seu marido ${ }^{110}$. Dessa forma garantia-se que as mulheres tivessem as condições necessárias para prover o sustento dos seus filhos, desempenhando, assim, adequadamente o seu papel social.

\section{As pedras e seus usos femininos: a menstruação e o aleitamento}

A menstruação é um tema recorrente no LAX. Ao todo são apresentadas seis pedras que têm entre as suas virtudes oferecer tratamentos relacionados à menstruação. Abaixo reproduzimos uma tabela com o nome das pedras indicadas para os tratamentos relativos ao ciclo menstrual, o signo e o grau que devem ser observados no processo de manipulação das pedras, a natureza e a virtude que indicam a sua utilização e o local onde elas podem ser encontradas.

\begin{tabular}{|l|l|l|l|l|}
\hline Nome & Signo & Grau & Natureza & Local \\
\hline De Baran & Touro & 14 & Fria e Seca & África \\
\hline Sedinech & Sagitário & 2 & Quente e Seca & Egito \\
\hline Cornelina & Capricórnio & 6 & Fria e Seca & $\begin{array}{l}\text { Terras da Arábia, } \\
\text { lêmen e Roma }\end{array}$ \\
\hline
\end{tabular}

\footnotetext{
${ }^{107}$ FR, III, I, 4.

${ }^{108} \mathrm{FR}, \mathrm{III}, \mathrm{I}, 6$

${ }^{109} \mathrm{FR}, \mathrm{IV}, \mathrm{V}, 2$.

${ }^{110} \mathrm{FR}, \mathrm{III}, \mathrm{VI}, 3$.
} 


\begin{tabular}{|l|l|l|l|l|} 
Talc & Capricórnio & 10 & Fria e Seca & $\begin{array}{l}\text { lêmen, Haruquia e } \\
\text { Cabroz. (Cabriz?) }\end{array}$ \\
\hline Capcia & Capricórnio & 14 & Fria e Seca & Egito \\
\hline $\begin{array}{l}\text { Piedra del } \\
\text { azul }\end{array}$ & Capricórnio & 22 & Fria e Seca & $\begin{array}{l}\text { Muitos lugares, } \\
\text { mas a melhor em } \\
\text { Horacen }\end{array}$ \\
\hline
\end{tabular}

Tabela 1 - pedras para menstruação

Uma análise inicial dessa tabela nos leva a concluir que a maioria das pedras se encontra relacionada ao signo de capricórnio e se caracterizam por serem frias e secas. Somente aqueles que conheciam o zodíaco eram capazes de ler as cartas celestes e de explorar com sucesso as qualidades das pedras expondo-as às condições astrológicas ideais. Ao explicar a forma como o conhecimento astrológico foi apresentado no LAX, Rabelo informa que:

[...] a sistematização das pedras parte inicialmente da observação, de acordo com a Astronomia, dos movimentos e posições dos planetas. Depois, baseia-se na Astrologia, considerando-se que as virtudes das pedras mudam muitas vezes de acordo com o estado dos planetas e das figuras localizadas no oitavo céu.

Assim, as pedras encontram-se vinculadas, por um lado, aos planetas, que exercem influências mais fortes sobre elas, e, por outro, às conjunções por eles formadas com outros planetas, dependendo de sua posição. ${ }^{111}$

Era importante, portanto, observar-se os graus astronômicos existentes no momento da manipulação das pedras para que o seu efeito profilático fosse potencializado. Por isso, o LAX previa, no caso da maioria das pedras usadas para o tratamento dos males menstruais, que o momento mais adequado para a sua utilização se daria sob os auspícios do planeta Júpiter. ${ }^{112}$

Obedecendo ao pensamento analógico da cura pelos contrários, nota-se que a maioria das pedras indicadas para o tratamento de fluidos femininos, como o sangue

${ }^{111}$ RABELO. Op. cit, p. 142-143.

112 Ende ha mester que quien de esto quisiere obrar, que pare mientes al planeta Júpiter, que sea bien recibida de aquella estrella con que hiciere su obra, y otrosí al señor de la faz, que sea en buen estado para las obras de bien, y páralas del mal el contrario. LAX, p. 86. 
menstrual e o leite materno, têm a frieza e a secura como as suas qualidades mais exaltadas.

As pedras Cornelina e Capcia eram claramente indicadas para o tratamento dos males referentes ao sangramento menstrual excessivo. A Cornellina (em latim ou alaaquic en griego) uma pedra avermelhada que chamava a atenção dos homens pela sua beleza, podia ser encontradas nas minas localizadas Terras da Arábia, lêmen e Roma. Pela descrição apresentada no LAX, a Cornellina, se utilizada sob os auspícios da "estrella que es en el cabo delantero del cuerno, otrosí delantero, del Capricornio"113, poderia curar dores na garganta e ser utilizada para limpar os dentes, mas sua qualidade principal era "[...] estancar la sangre que corre mucho et mayormientes á las mugieres cuando les sale mas que no debe. ${ }^{114}$.

A Capsia (ou Capadócia), conseguida no Egito, é verde escura e maleável a ponto de ser facilmente quebrada para que, após triturada fosse possível produzir um pó facilmente diluído na água, sem que se altere o sabor, mas também poderia ser administrada diretamente sobre uma ferida para estancar o sangramento. Quem manipulasse a pedra sob os auspícios da "estrella septentrional de las tres que son en las péñolas del ala diestra de la Gallina ${ }^{115 "}$ gozaria do seu poder e "de ella recibe la fuerza y la virtude"116.

A pedra de Baran, de cor parada e encontrada nas minas africanas, se utilizada sob os auspícios da "estrella que es en el muslo del brazo siniestro de la imagen de Tauro" que tem "señorío sobre esta piedra y de ella recibe la fuerza y la virtude", poderia estancar sangramentos quando colocada sobre uma chaga ou ferida. Na descrição da pedra destaca-se a propriedade que ela possui de estancar o sangue feminino, especialmente se "cuando la muelen et la amasan com vinagre et facen de ella bellotus et las ponen sobre la natura de la mugier"117

\footnotetext{
${ }^{113}$ LAX, p. 87.

${ }^{114}$ LAX, p. 49.

${ }^{115} \mathrm{~A}$ constelação da galinha era chamada assim pelos árabes. Atualmente essa mesma constelação recebe o nome de Cisne.

${ }^{116}$ LAX, p. 90.

${ }^{117}$ LAX, p. 11.
} 
Esse é o caso também da pedra Talc (ou Alfath, em árabe) encontrada nas terras de Haruquia, lêmen e Cabroz. Da cor das conchas, se esfolada, essa pedra "[...] fuerza há de retener mucho, et por end faz quedar la sangue al que la escupe por alguna enfermedad que haya; et eso mismo faz á las mugieres cuando les sales mas que no conviene. ${ }^{118}$

Enquanto as pedras mencionadas até aqui se referem diretamente ao sangramento feminino, as descrições apresentadas sobre as pedras Sedinech e a Piedra del Azul utilizam uma linguagem metafórica para referir-se à menstruação, que é equiparado a uma flor, conforme observa-se nos trechos abaixo:

Del seguno grado del signo de Sagitario es la piedra á que dicen Sedinech. (...) Et otrosi á las mugieres que hán enfermedad por razon que les viene mucho su flor, faz que lo pierdan. ${ }^{119}$

Del XXII del signo de Capricornio es la piedra del Azul. (...) Et otrosi há vertud de facer venir su flor á la mugier em el tiempo que debe tan vien por berbela como por ponerla em la natura. ${ }^{120}$

Associar a menstruação à floração é uma metáfora comum na Idade Média. A médica Trotula de Salerno, por exemplo, já no século XI comparava a menstruação às flores, pois assim como elas possibilitam às árvores produzir frutos, as mulheres necessitam da menstruação para engravidar. ${ }^{121}$

Outra pedra indicada para o tratamento dos males menstruais é a Sedinech. Sua constituição, ao contrário das outras pedras mencionadas até aqui, é quente e seca, sendo indicada para o tratamento das dores ou cólicas menstruais. O LAX diz "Et otrosi á las mugieres que hán enfermedad por razon que les viene mucho su flor, faz que lo pierdan." ${ }^{\prime 22}$ No caso do tratamento das cólicas menstruais, recomenda-se que a pedra

\footnotetext{
118 LAX, p. 50.

${ }^{119}$ LAX, p. 43.

120 LAX, p. 52

${ }^{121}$ THOMASSET, Claude. Da natureza feminina. In: DUBY, Georges; PERROT, Michelle. (org.). História das mulheres no ocidente. Vol 2: A idade Média. Santa Maria da Feira: Rainho \& Neves. 1990. p. 78.

${ }^{122}$ LAX, p. 43.
} 
fosse bebida com vinho potencializar o seu efeito. A ingestão da pedra também foi indicada no uso Piedra del Azul que, para "facer venir su flor á la mujer en el tempo" dever ser bebida ou posta "en la natura"123.

Os males menstruais também poderiam ser tratados com o uso das pedras Baran e Talc. Nesse caso, as pedras devem ser utilizadas diretamente na vagina, ou em forma de bolas feitas com vinagre e o pó da pedra, que deveriam ser administradas no local, como é o caso da pedra Baran, ou untando-se o órgão, como se propunha para Talc. Já no caso das pedras Cornelina e Capcia não foram oferecidas instruções sobre a forma da sua utilização, o texto somente indica as possibilidades do seu uso nesses casos.

A presença dos tratamentos referentes ao sangramento feminino no LAX, e mesmo a sua assimilação com a ideia da floração, denota a importância que o equilíbrio menstrual possuía tanto para a preservação da mulher enquanto pessoa quanto para permitir que ela cumprisse adequadamente o seu papel de reprodutora, por excelência, do corpo social.

Imersas em uma cultura que entendia que a principal função feminina era a garantia da reprodução grupal, as mulheres medievais tiveram os seus corpos entendidos a partir de um conjunto de símbolos e significados que em geral não levava em consideração as demandas femininas. Maria-Milagros Rivera ${ }^{124}$, ao analisar a "querela das mulheres", esclarece-nos quanto ao conceito de corpo feminino imperante na tradição medieval, especialmente a eclesiástica. De acordo com os variados escritos teológicos do período, que por vezes utilizavam referências advindas do saber médico, o corpo feminino era considerado inferior ao corpo masculino tanto em potência quanto em virtude. Além disso, pela sua natureza, o corpo da mulher poderia se tornar uma fonte inesgotável de tentações, dada a sua aparência caráter sedutor, lançando os homens às práticas pecaminosas.

Avançando nessa reflexão sobre a concepção da cultura religiosa e intelectual medieval em torno do corpo feminino consideramos que uma das manifestações

\footnotetext{
${ }^{123}$ LAX, p. 32.

124 RIVERA, María-Milagros. El cuerpo feminino y la "querela" de las mujeres (Corona de Aragón, siglo XV). In: DUBY, G. e PERROT, M. Historia de las mujeres. Huellas, imágenes y palavras. Madrid: Taurus, tomo 4, 1992.
} 
corporais mais fortes e elementares, e que marca profundamente a identidade feminina, é justamente o sangue menstrual.

No âmbito teológico a concepção cristã acerca da menarca desenvolveu-se com base na tradição judaica, posteriormente também encampada pelo Islã. Lembrando que o LAX é um tratado originário da cultura oriental, que foi apropriado, na corte afonsina por uma perspectiva cristã, ele traz em si a confluência de diversos saberes, dentre eles o judaico e o islâmico.

Dentro da concepção judaica e muçulmana, a menstruação seguia a mesma lógica da polução noturna. Apesar de ser entendia como parte da fisiologia feminina, ela é considerada impura. O Velho Testamento, por exemplo, indicava às mulheres que buscassem a purificação do seu corpo logo após o ato impuro da menstruação. Durante o período da menstrual a mulher era tida com nidah, ou seja, aquela que deveria ser separada. Nesse momento estava vetada a ela frequentar lugares específicos, como o templo, e desempenhar algumas atividades ${ }^{125}$.

As restrições impostas às mulheres no período menstrual foram debatidas durante a Idade Média por sábios como Maimônides (1135-1204). Assim como os judeus, os muçulmanos consideravam as mulheres impuras durante o período menstrual, onde elas eram também proibidas de manter relações com o seu marido e sofriam restrições nas liturgias cotidianas, como o jejum, as preces, as leituras etc.

A menstruação também foi considerada como uma impureza na teologia cristã, mas a rigidez de prescrições comportamentais em torno desse tema foi suavizada pelo cristianismo. No século VI, por exemplo, Gregório Magno determinou que as mulheres não deveriam ser impedidas de entrar na igreja durante a menstruação. Contudo, ao contrário das determinações judaicas e islâmicas, o cristianismo não previa a existência de um processo ritualístico de purificação. ${ }^{126}$

\footnotetext{
${ }^{125}$ Para sair do status de tamé (impura) e conseguir se tornar tahor (pura), a mulher deveria passar por um ritual de limpeza tomando um banho. Esse banho não marca só a limpeza do corpo, mas também, da alma. O espaço do banho é chamado de micvah. LANDMANN, Jayme. Sexo e judaísmo. Rio de Janeiro: Eduerj.1999. p. 144-145

${ }^{126}$ GREEN, Monica H.. Flowers, Poisons and Men: Menstruation in Medieval Western Europe. In: SHALL, Andrew; HOWIE, Gillian. (Ed.). Menstruation A Cultural History. Londres: Palgrave Macmillan UK. 2005. p. 51-54.
} 
Isso não quer dizer que a menstruação tenha perdido seu caráter impuro aos olhos do cristianismo, na verdade estava bastante presente nos discursos e no imaginário cristão. Influenciados por Plínio, alguns teólogos entenderam que a menstruação poderia matar as colheitas, azedar o leite e causar a ferrugem. Até mesmo um debate acerca da menstruação de Maria foi estabelecido durante o período medieval em decorrência da discussão em torno da sua santidade. Além disso, foi parte do discurso religioso medieval a ideia de que o sexo feito com uma mulher menstruada era a causa da lepra e de outros tipos de deformidades físicas. ${ }^{127}$

Por ser parte da fisiologia feminina, a menstruação foi um tema recorrente na medicina medieval, especialmente quando se identificava algum impedimento físico ao seu pleno desenvolvimento. O sangue menstrual foi entendido, em termos médicos, de duas maneiras: como resultado de purificação dos humores e como requisito fundamental para a fecundação.

O principal alvo de medicalização das questões referentes ao ciclo menstrual estava na retenção do fluxo e no estancamento dos sangramentos. Apesar de ser corrente no pensamento médico medieval que o sangue menstrual resultava de um processo de purificação interna dos órgãos reprodutores femininos ${ }^{128}$, a perda excessiva de sangue poderia resultar do desequilíbrio do corpo feminino, gerando doenças e impedindo a procriação. Daí no AXL encontrarmos menções às pedras que podem restaurar o equilíbrio do corpo impedindo os sangramentos.

Das cinco pedras recomendadas para conter o excesso de fluxo menstrual (Pedra de Baran, Cornelina, Talc e Capcia), somente uma delas, a Piedra del Azul se destina a expelir a menstruação retida. Essa diferenciação pode ser entendida a partir dos elementos que apontamos anteriormente. No campo religioso a presença da menstruação era algo que causava estranheza e mal-estar, já que se tratava de uma marca de impureza que contaminava tudo a sua volta, além disso, causava às mulheres sérias restrições que impossibilitavam o pleno exercício da sua fé. Talvez por isso

\footnotetext{
127 Ibid., p. 57-59.

${ }^{128}$ Ibid., p. 54-55.
} 
houvesse a indicação do uso de pedras que ajudassem a diminuir o fluxo menstrual e retirassem a mulher do seu estado de impureza.

Contudo, tomando como parâmetro o saber médico propriamente dito, reter a menstruação poderia ser uma forma de auxiliar na reprodução. De acordo com a teoria aristotélica, a menstruação era equivalente ao esperma. Se para o homem a ejaculação era considerado o fluido da vida, para a mulher, a menstruação cumpria esse papel. Dessa forma, o controle do fluxo menstrual poderia garantir um certo controle sobre a fertilidade feminina. Já Galeno acreditava que o corpo feminino produzia "esperma" no momento da lubrificação, logo o sangue menstrual não se encontrava diretamente relacionado à fecundação, pois reter a menstruação auxiliava na regulação dos humores femininos. Galeno entendia que o os fluidos corporais passavam por processos de cozimento, sendo assim, o sangue menstrual retido durante a gravidez se transformaria em leite materno. Contudo, a apesar dos benefícios do sangue menstrual, a menstruação não poderia ser abundante, pois o seu excesso poderia causar doenças nos seios, mas também não poderia ser diminuta, pois desregularia os humores, extinguindo o leite materno. ${ }^{129}$

O controle do ciclo menstrual, apesar de ser um assunto diretamente relacionado às mulheres e ter um caráter pessoal, na cultura medieval tratava-se também de um assunto social, assim como todos aqueles que se relacionavam à garantia das boas condições de reprodução. A capacidade reprodutiva de uma mulher era fundamental para assegurar a ela não só a possibilidade de casar-se, mas também de manter-se casada. Das mulheres era esperado que gerassem herdeiros em abundância e de preferência do sexo masculino, sempre em condições de legitimidade matrimonial.

A importância do casamento era considerável na tradição eclesiástica medieval, que recomendava que as pessoas, em geral, se casassem. Entretanto, nos primeiros séculos da Idade Média, a tendência do discurso clerical era considerar o casamento como uma espécie de mal necessário e atribuir-lhe um espaço moralmente inferior em relação às práticas ascéticas. Um dos maiores representantes do pensamento ascético,

${ }^{129}$ Vf. GREEN. Op. cit, p. 57-60 e THOMASSET, C. op. cit. p. 79. 
S. Jerônimo estabeleceu uma espécie de divisão moral para a sociedade medieval na qual os virgens estavam no ápice, sendo seguido pelos viúvos e aos casados era reservada a base piramidal. Por estarem constantemente expostos à prática do pecado carnal, os casados eram aqueles que se encontravam distantes do comportamento ascético ideal por necessitarem cumprir a função de reprodutores do corpo social.

A predominância do pensamento ascético na Idade Média explica a pouca valorização que o casamento encontrou na literatura e na iconografia eclesiástica alto medieval, especialmente pela ligação indissolúvel que mantinha com as práticas sexuais. Georges Duby nos lembra:

[...] O casamento seria perfeitamente bom, se toda a jubilação do corpo dele fosse proscrita. É impossível chegar a este ponto. O prazer só pode ser "governado", dominado. Logo, o casamento é sempre uma "falta", e é por tal motivo que todos os laicos, inclusive os reis, estão subordinados aos puros, os sacerdotes. ${ }^{130}$

Ao analisar as representações iconográficas acerca do casamento, Chiara Frugosi ${ }^{131}$ observou que até o século XI foram raríssimas as representações das bodas de Maria e José, mas que se tornaram mais frequentes a partir do momento em que os ideais reformistas eclesiásticos se efetivaram e o casamento foi alçado ao status de sacramento.

A transformação do casamento em um sacramento eclesiástico não se deu sem resistência por parte dos setores nobiliárquicos, tradicionalmente responsáveis por cuidar da regulamentação e da legitimidade das relações matrimoniais. Dentro do que Georges Duby (1990) denominou "moral laica", aos eclesiásticos cabia somente o papel simbólico e cerimonial de ungir o leito matrimonial na noite de núpcias a fim de garantir as bênçãos divinas para assegurar a fertilidade da união. Contudo, conforme os ideais reformistas da Igreja se consolidavam no século XI, uma "moral eclesiástica" em torno do casamento foi propagada diretamente de Roma para o restante do ocidente, e nela,

\footnotetext{
${ }^{130}$ DUBY, G. O cavalheiro, a mulher e o padre. Lisboa: Publicações Dom Quixote, 1988, p. 86.

${ }^{131}$ FRUGOSI, Chiara. La mujer en las imágenes, la mujer imaginada. DUBY, G. e PERROT, M. Historia de las mujeres. Huellas, imágenes y palavras. Madrid: Taurus, tomo 4, 1992.
} 
a Igreja reivindicava para si a autoridade de regular as relações matrimoniais que passaram a ser entendidas como sacramentais. Analisando as duas morais matrimoniais, Duby concluiu que o modelo laico encontrava-se enraizado no patrimônio fundiário e o modelo eclesiástico, em procedimentos morais que objetivavam refrear os impulsos da carne e controlar a sexualidade ${ }^{132}$, o que os levou ao conflito.

Em termos práticos, o casamento deixaria de ser realizado na residência dos pais dos noivos e passaria a ser celebrado em edifícios religiosos, sendo a cerimônia obrigatoriamente conduzida por um eclesiástico, que recitaria o rito matrimonial. Além disso, o casamento só poderia ser efetuado com o consentimento dos noivos e a concessão do divórcio se daria somente com a autorização do papado e atendendo a circunstâncias determinadas, como, por exemplo, a infertilidade feminina.

A capacidade de fertilidade que uma mulher possuía, portanto, era primordial para garantir o seu lugar no círculo familiar que ela passaria a integrar após o casamento. Logo, cuidar da saúde feminina, evitando que as mulheres tivessem a sua capacidade reprodutiva dificultada pelo excesso ou pela perda de sangue, não se tratava de algo que cabia somente às próprias mulheres, mas também à sua parentela e àqueles que possuíam o conhecimento médico tratadístico.

Ao contrário da menstruação, o leite materno não era considerado um tabu, e muito menos algo mal visto pela sociedade medieval, sendo, ao contrário, altamente valorizado. A cultura medieval atribuiu ao leite materno uma forte carga simbólica atrelada, especialmente, à ideia de provisão. No LAX encontramos duas pedras que oferecem tratamentos quanto à potencialização da produção do leite materno.

A primeira pedra é a Zarocan, que se encontra no primeiro grau do signo de gêmeos, e pode ser encontrada por todo o "mundo conhecido", mas as melhores, diz o AXL, eram aquelas encontradas na Espanha e na Barbaria ${ }^{133}$. A estrela a ela referente é a que se encontra no rabo da constelação da Ursa Menor. Descrita como uma pedra

\footnotetext{
132 DUBY, G. Idade Média. Idade dos Homens. Do amor e outros ensaios. São Paulo: Companhia das Letras, 1990.

${ }^{133}$ Barbaria é a denominação dada à costa norte da África, região dos Berberes.
} 
branca, clara, mas não o bastante para ser transparente, ela é forte e dura de quebrar, porém é leve. Sua natureza é quente e úmida. ${ }^{134}$

Sobre as suas propriedades o LAX diz:

La vertud desta piedra es á tal que face crescer mucho la leche á las mugieres que la traen. Et eso mismo face á outro animal cual quier. Et por end los barbaros las facen traer á suas mugieres á los cuellos segund traen el aliofár. Et presta otrosi para esto mismo cuando la meten em lectuarios et la dan á comer. ${ }^{135}$

Além dessas foram relatadas outras propriedades da pedra como o seu uso no tratamento da melancolia e das feridas que aparecem nos olhos. ${ }^{136}$

A segunda pedra mencionada é a Axufaraquid, a décima quinta pedra do signo de virgem. Forte, leve e porosa, ela é encontrada na terra do ocidente ${ }^{137}$, no fundo de um rio não identificado na fonte. A estrela que está no lado direito da cinta da constelação de virgem é a seu referente. Em relação a suas virtudes a fonte diz que:

Et ha tal vertud que si la untan em sangre de cabron caliente desfazse et mezelase com ella et si de aquella sangre mezclaren com mirra et com miel, et untaren com ella la lengua del que la há embargamiento et fabla escorrendo.Et si untarem com ella las tetas de las mugieres crescerles há mucho la leche. ${ }^{138}$

Sobre as suas virtudes há na fonte uma informação incomum:

De natura es fria et seca et las sus vertudes son cont rarias á su natura, et esta es una de las grandes maravilhas que son falladas em las vertudes que hán las cosas em si naturalmente."139

Na tradição medicinal da Idade Média, o sangue menstrual era transformado em leite materno através da ação do organismo feminino. Contudo, para que esse processo

\footnotetext{
${ }^{134}$ LAX, p. 15

135 Idem

${ }^{136}$ Ibid

137 Ocidente é a denominação árabe ao que conhecemos como Europa.

138 LAX, p. 29.

139 Idem
} 
ocorresse era necessária a cocção, ou seja, o calor. Ora, a natureza da pedra Axufaraquid é fria e seca, o que a princípio não seriam características favoráveis ao desenvolvimento da cocção. Se a mulher é fria por si e para fazer a transformação do fluido é necessário calor, como um corpo frio ao ingerir uma pedra fria, produziria o leite materno? Esse mistério é resolvido pelo autor do LAX ao informar que fazer essa cocção é uma virtude natural da pedra, demonstrando que a característica da gema era alterada conforme as condições astronômicas de uso, evidenciando, assim, que as forças dos astros eram transformadoras e misteriosas.

Na cultura medieval o leite materno era entendido como o símbolo por excelência da experiência da maternidade. Por mais que o uso das amas de leite fosse comum, especialmente entre as mulheres nobres, a mãe deveria demonstrar a sua capacidade de exercer a maternidade provendo o sustento do seu filho. Entre as mulheres de outros agrupamentos sociais ainda mais se fazia necessário que a mãe tivesse a capacidade de garantir que o seu filho sobrevivesse à primeira infância, prejudicada pelas condições adversas decorrentes de uma produção alimentar na maioria das vezes precária.

Os símbolos da cultura religiosa judaica, onde exemplos de mães que amamentam os seus filhos encontram-se presentes (vide a história da mãe de Moisés que, mesmo sendo obrigada a afastar-se do seu filho, tornou-se a sua ama de leite ${ }^{140}$ ), foram fortemente utilizados na cultura medieval para referendar o papel social da maternidade. O leite materno foi representado em diversas figuras eclesiásticas como Saint Mammant ou São Mamete. Cultuado desde o século VIII, Mammant teve a sua história marcada pelo aleitamento. O santo teria vivido no século III, sendo perseguido pelo Império Romano. Sofrendo perseguição, Mamete teve que se alimentar do leite de

\footnotetext{
${ }^{140}$ No Judaísmo, a importância da amamentação é percebida em histórias como a de Moisés, em que a sua mãe tornou-se a ama de leite da filha do faraó. Em outras, como a de Samuel, nota-se que, mesmo prometido por sua mãe para servir no templo, ele só foi dado ao sacerdote após três anos de vida, depois do desmame. Dentro do Tamulde, encontramos a indicação de que a mãe deveria amamentar o seu filho até os 2 anos. Essa recomendação, dizia, era importante para a preservação da sua vida.
} 
vários animais. Em uma dessas fugas ele encontrou um bebê abandonado e nesse momento Deus deu ao santo a habilidade de produzir leite e, assim, salvar bebê. ${ }^{141}$

Outra representação sobre a amamentação pode ser encontrada na figura da Virgem do Leite, ou Nossa Senhora do Leite, denominação dada às representações de Maria amamentando o menino Jesus. O culto a essa Virgem pode ser datado no século II, mas foi durante o século XII e XIII que, juntamente com a ascensão da imagem de Maria no imaginário cristão, que a virgem lactante ganhou força e mais espaço entre os fiéis.

A partir daí, várias outras representações em torno da amamentação surgiram na cultura medieval, como a de São Bernando, que por causa da sua grande devoção, recebeu o leite materno diretamente dos seios da Virgem. Assim, o santo foi curado das suas dores e, através do leite de Maria recebeu a eloquência para pregar as palavras celestiais. Esse episódio ficou conhecido como "A lactação de São Bernardo". Outras imagens similares foram sendo elaboradas nos relatos hagiográficos ao longo do tempo, como os produzidos em torno de santos como São Pedro Nolasco, São Domingos, São Caetano, Santo Agostinho e São Vicente. ${ }^{142}$ Através desses exemplos podemos perceber a carga e a representativa simbólica que o leite materno alcançou na cultura cristã medieval.

Na cultura islâmica, Al Razi atribuiu ao profeta Maomé a frase: "As proibições do leite são idênticas às proibições do sangue", que se refere às proibições sexuais existentes entre os parentes de sangue. No Islã, o parentesco de leite era simbólico e de grande importância, a tal ponto que se estabelecia a proibição das relações sexuais entre pessoas que estivessem ligadas por esse tipo de laço. Os casos de proibições sexuais contra consanguíneos se aplicavam aos irmãos de leites e às suas famílias. Al Razi mais

\footnotetext{
${ }^{141}$ SIBILIA, Paula. The "pornification" of the gaze: A genealogy of the nude breast. In: Thinking the body as a basis, provocation and burden of life : studies in intercultural and historical contexts. MELVILLE, Gert; RUTA, Carlos; CARUGATI, Laura. Berlin: De Gruyter Oldenvourg. 2015. p. 211. ; SANDRE-PEREIRA, Gilza. Amamentação e sexualidade. Estudos Feministas, Florianópolis, 11(2): 360, jul/dez. 2003. p. 469470.

${ }^{142}$ SIBILIA, op. cit., p. 209-2012.
} 
uma vez afirma que: "Em denominado a ama de leite mãe e os co-lactantes irmãos, Allah deu ao aleitamento a mesma amplitude da consanguinidade.". ${ }^{143}$

Em momentos de crises ou de crescimento, como aquele identificado no século XII, percebemos o papel do leite materno na garantia do aumento demográfico e na baixa da mortalidade infantil. Alberto Magno se preocupou com as mulheres pobres que não se alimentavam bem e trabalhavam muito, produzindo o que chamamos hoje de amenorreia, que influenciava tanto o processo de fecundação quanto de lactação, já que a mãe não teria fluidos suficientes para manter a vida e a saúde do seu bebê. ${ }^{144}$

Tanto o controle da menstruação quanto o do aleitamento relacionam-se à lógica matrimonial da sociedade medieval. Os cuidados com a menstruação relacionavase também ao controle da dinâmica sexual do casal e de uma possível gestação. Ter fluxos menstruais equilibrados garantia ao casal maior disponibilidade e regularidade nas relações sexuais, ampliando-se, assim, as probabilidades de procriação. Já o aleitamento adequado garantia a manutenção da prole. Os filhos só seriam bem alimentados se tivessem leite em abundância e de qualidade para garantir-lhes a sobrevivência nos anos de maior fatalidade que eram os da primeira infância. Assim, quer fosse pelo controle do ciclo menstrual, quer fosse pela garantia do aleitamento, a sociedade medieval contribuía para que o matrimônio se tornasse o palco central onde as mulheres cumpriam os papéis sociais determinados para elas.

Apesar de historiadores como Monsalvo ${ }^{145}$ entenderem o LAX como um tratado imerso no campo do pensamento mágico, não fazendo parte da obra científica produzida na corte afonsina, o fato é que as informações nele presentes circulavam nos ambientes intelectuais do reino castelhano e tanto foram valorizados pelo monarca e pelo seu scriptorium que foi por ele traduzido, juntamente com um conjunto de outras obras "científicas".

Contrapor o pensamento mágico ao conhecimento produzido supostamente sobre as bases da experimentação não nos parece um caminho analítico interessante

\footnotetext{
${ }^{143}$ BOUHDIBA, Abdelwahab. A sexualidade no Islã. São Paulo: Globo, 2006. p. 32-33.

${ }^{144}$ THOMASSET, Claude. Op. cit, p. 79.

${ }^{145}$ MONSALVO, Op. cit. p.
} 
para o estudo das obras tratadísticas medievais visto que não havia distinção possível entre eles. De acordo com a lógica tomista, todo o conhecimento produzido pelo homem busca, sobretudo, a aproximação com o divino, ou em equivalência, com o mágico.

O conhecimento astrológico da antiguidade serviu como base para que os padres da Igreja refletissem sobre a sua relação com o divino através das forças celestiais. Foi esse o caso de Isidoro de Sevilha, bispo e intelectual visigodo, que dividiu a astrologia em duas partes: a astrologia supersticiosa e a astrologia naturalis. A astrologia supersticiosa tinha a função de prever o futuro e o destino, já a astrologia naturalis buscava o entendimento do mundo e das coisas naturais, sendo incentivada e não considerada contraditória em relação à doutrina cristã, pois a sua função era principalmente meteorológica e medicinal. A valorização da astrologia naturalis encontra-se expressa no LAX, como se observa no trecho a seguir:

Et este libro es muy noble et muy preciado: et qui dél se quisiere aprovechar, conviene que pare mientes en tres cosas. La primera, que sea sabidor de astronomía, porque sepa connoscer las estrellas, en cual estado están, y en cual sazón viene mayor vertud á las piedras dellas, segund la vertud que reciben de Dios. ${ }^{146}$

Até mesmo grandes nomes da igreja dialogavam com a astrologia, como Alberto Magno e Tomás de Aquino. Para os escolásticos, os astros eram sinais materiais da força divina expressa na natureza, portanto, influenciavam o corpo físico e os seus impulsos. Sendo assim, o campo privilegiado da astrologia era a medicina. Já que os astros influenciavam de forma direta e mais fortemente os corpos físicos presentes no mundo sublunar, a medicina deveria levar sempre em conta as configurações astrológicas. Como afirma Helen Rodnite Lemay ${ }^{147}$ a astrologia e medicina encontravam-se interligadas no período medieval, sendo a medicina a base para a prática astrológica.

\footnotetext{
${ }^{146}$ LAX, p. 1.

147 LEMAY, Helen Rodnite. Human sexuality in twelfth-through fifteenth-century scientific writings. In: BULLOUGH, Vern L.; BRUNDAGE, James. Sexual pratices \& the medieval church. New York: Prometheus Books, 1994. p. 192.
} 
Muitas obras astrológicas foram incorporadas aos currículos das universidades medievais, por isso não é incomum encontrarmos tratados astrológicos escritos por físicos.

É preciso lembrar ainda que a influência astrológica dialogava com as grandes correntes de pensamento na antiguidade e podemos encontrar no LAX a influência de Aristóteles, Dioscórides, Hipócrates e Galeno. Logo, o conhecimento que hoje caracterizamos como místico e mágico baseou os saberes médicos presentes nas informações expostas no LAX.

\section{Conclusão}

O cuidado com a saúde das mulheres era vital na sociedade medieval em função do papel central que elas desempenhavam na sua reprodução física, mas também patrimonial. As mulheres deveriam estar com os seus corpos físicos prontos para servir ao corpo social, do qual o rei era o cabeça. Aplicando-se o conhecimento médico, inclusive aquele previsto no LAX, assegurava-se que o corpo feminino estivesse pronto para a reprodução, através de uma menstruação saudável, e para amamentação, garantindo que seus filhos gozassem de boa saúde e da sua herança. Além disso, a saúde do corpo da mulher Ihe garantia um status diferenciado naquela sociedade onde a precariedade da alimentação, em quantidade e em variedade, era uma realidade e a taxa de mortalidade de crianças recém-nascidas e de mulheres era alta. A boa saúde da mulher era um requisito importante no seu posicionamento como mãe e como esposa, oferecendo-Ihe as condições ideais para que desempenhasse adequadamente os seus papéis sociais principais. O corpo feminino sujeitava-se, assim, ao corpo social.

\section{Referências Bibliográficas}

\section{Documentação}

AFONSO X. Lapidário del Rey D. Alfonso X: Códice original. Madrid: Imprenta de La Iberia. 1881.

ALFONSO X. Las siete partidas de Don Alfonso X. Barcelona: Imprenta de Antonio Bergnes, 1843-1844. 
FUERO REAL de Alfonso X El Sabio. Edición de La Real Academia de la Historia, 1836. In: Colección Leyes Históricas de España. Estudio preliminar de Antonio Pérez Martín. Madrid: Imprenta Nacional de La Agencia Estatal Boletín Oficial del Estado, 2015.

\section{Bibliografia}

BOSI, Maria Lúcia M.; MACHADO, Márcia Tavares. Amamentação: um resgate histórico. Cadernos ESP - Escola de Saúde Pública do Ceará. Fortaleza. v. 1 - n. 1 - Jul/Dez, 2005. BOUHDIBA, Abdelwahab. A sexualidade no Is/ã. São Paulo: Globo, 2006.

DUBY, G. O cavalheiro, a mulher e o padre. Lisboa: Publicações Dom Quixote, 1988. . Idade Média. Idade dos Homens. Do amor e outros ensaios. São Paulo: Companhia das Letras, 1990.

FRANCO Jr. Hilário. Similibus simile cognoscitur. O pensamento analógico medieval. Medievalista. Lisboa, v. 14, 2013. p. 8-14.

GREEN, Monica H.. Flowers, Poisons and Men: Menstruation in Medieval Western Europe. In: SHALL, Andrew; HOWIE, Gillian. (Ed.). Menstruation A Cultural History. Londres: Palgrave Macmillan UK. 2005.

FRUGOSI, Chiara. La mujer en las imágenes, la mujer imaginada. DUBY, G. e PERROT, M. Historia de las mujeres. Huellas, imágenes y palavras. Madrid: Taurus, tomo 4, 1992.

MATTOS, Carlinda Maria Fischer. A classificação dos seres no Lapidário de Afonso $X, O$ Sábio. 2008. 298 f. Tese (Doutorado em História) - Instituto de Filosofia e Ciências Humanas, Universidade Federal do Rio Grande do Sul, Porto Alegre. 2008.

MONSALVO, J. M. A. Rey y reino. Realeza, espacios políticos y poderes em las monarquias hispânicas (siglos XI - XIII). In: Historia de la España Medieval. Salamanca: Universidad de Salamanca, 2018.

ORLANDIS, E. P. Análise de discurso. Princípios e procedimentos. Campinas: Pontes, 2012.

RABELO, D. R. S. Um olhar para o céu e para as pedras: conhecimento científico no Lapidario de Afonso X de Castela (século XIII). 198 f. Tese (Doutorado em História) Programa de PósGraduação em História da Universidade Federal de Goiás (UFG). Goiânia, 2019. 
RIVERA, María-Milagros. El cuerpo feminino y la "querela" de las mujeres (Corona de Aragón, siglo XV). In: DUBY, G. e PERROT, M. Historia de las mujeres. Huellas, imágenes y palavras. Madrid: Taurus, tomo 4, 1992

SIBILIA, Paula. The "pornification" of the gaze: A genealogy of the nude breast. In: Thinking the body as a basis, provocation and burden of life : studies in intercultural and historical contexts. MELVILLE, Gert; RUTA, Carlos; CARUGATI, Laura. Berlin: De Gruyter Oldenvourg. 2015.

SALVADOR, Nicasio Miguel. El intelectual. In: VALDEÓN, J., SALVADOR, N, LÓPEZ ESTRADA, E. e MARÉN, M. La España de Alfonso X. Cuadernos Historia 16. v. 13, 1985

THOMASSET, Claude. Da natureza feminina. In: DUBY, Georges; PERROT, Michelle. (org.). História das mulheres no ocidente. Vol 2: A idade Média. Santa Maria da Feira: Rainho \& Neves. 1990. 